Research article

\title{
A PILOT STUDY ON SKIN POTENTIAL RECORDINGS AS A MEASURE OF NOCICEPTION IN PAIN-FREE DOGS AND HUMANS, AND IN DOGS WITH PERSISTENT PAIN
}

\author{
GIORDANO Paola ${ }^{1 *}$, BENNETT C Rachel ${ }^{2}$, DRIESSEN Bernd ${ }^{3}$ \\ ${ }^{1}$ Massey University, The Institute of Veterinary, Animal and Biomedical Sciences (IVABS), Palmerston \\ North, New Zealand; ${ }^{2}$ University College of Dublin, School of Veterinary Medicine, UCD Veterinary \\ Sciences Centre, Dublin, Ireland; ${ }^{3}$ University of Pennsylvania, School of Veterinary Medicine, Dept of \\ Clinical Studies - New Bolton Center, Philadelphia, USA
}

(Received 30 March, Accepted 25 December 2017)

The Pain Trace ${ }^{\mathrm{TM}}$ device can detect changes in the skin's electrical potentials claimed to be associated with pain related alterations in the sympathetic and parasympathetic nervous system activity. Positive voltages represent the absence of major pain, whereas negative voltages represent moderate to severe pain. Unlike in humans and horses, no baseline skin potential recordings have been reported in dogs. In study Part 1 baseline skin potentials were recorded in healthy dogs and compared to readings obtained in human volunteers. In dogs, data were recorded with electrodes placed at three separate sites: neck, axilla, and thorax. In humans, data were collected from the palms. Readings over a 90-second period were averaged and comparisons between groups were performed using the Kruskal-Wallis test. All voltage recordings were positive. Readings in dogs had greater variability. Recordings from the thorax were more homogeneous, this being the reason why this site was chosen for study Part 2. No significant differences in recordings were noted between pain-free dogs and humans. The main hypothesis was that shifting from positive to negative skin potential voltages serves as an indicator of canine patients sensing moderate to severe pain. Therefore, we obtained preoperative readings from dogs with cranial cruciate ligament disease that were experiencing associated persistent pain, and compared these data with readings from pain-free dogs (thorax). In dogs undergoing surgery, all pre-surgery voltage readings were positive and thus no consistent relationship between skin potential recordings and pain perception could be established. Further investigation is needed to confirm any relationship between skin potential and pain severity in dogs.

Key words: Afferent pathway, autonomic nervous system, canine diseases, pain, electrodiagnosis

\section{INTRODUCTION}

The International Association for the Study of Pain (IASP) has defined pain as "an unpleasant sensory and emotional experience associated with actual or potential tissue

\footnotetext{
*Corresponding author: e-mail: P.Giordano@massey.ac.nz or pg.paolagiordano@gmail.com
} 
damage" and declared pain to be always subjective. The quantification of pain and therefore the choice of the appropriate method for pain relief remain challenging. The most commonly used method of pain assessment in humans is self-reporting, using either a Visual Analogue Scale, the Wong-Baker Faces Pain Rating Scale, or the Numeric Rating Scale for Pain. In animals, as in non-verbalizing pediatric human patients, pain assessment is far more challenging. The first validated method of acute pain assessment in small animals was the short form of the Glasgow Composite Measure Pain Scale (CMOS-SF), a behavior-based composite scale to assess acute pain and define a threshold for intervention with analgesics in dogs [1]. This is not an objective mean of assessing pain either, because it involves a trained observer (clinician or veterinary nurse) entering scores based on the observation of several behavioral variables; the individual animal is not directly communicating its pain experience. Therefore, the search for technologies that allow qualitative and quantitative measurements of nociception and pain, respectively, is continuing.

Measurements of natural endosomatic activity, also referred to as skin potential (SP), may be useful in detecting nociception and pain, because SP changes in response to painful stimuli are claimed to physiologically correlate with the known autonomic nervous system (ANS) activity changes in response to persistent pain in rats [2]. One device that allows the recording of SPs has been developed and marketed commercially under the trade name Pain Trace ${ }^{\mathrm{TM}}$ (Model 103A, Biographs Inc, Bayville, NY, USA; currently BioTraceIT, Philadelphia, PA, USA) and has been studied since 2005 for the assessment of persistent and chronic pain in humans with failed back syndrome [3-5] and in horses with musculoskeletal pain [6].

SP can be explained as an electric potential difference between two sites on the surface of the skin (also referred to as the Tarchanoff effect in electrophysiology). When surface electrodes are placed on the skin of mammals, a voltage gradient immediately becomes obvious because the skin itself acts as an electrical conductor. Thus, unlike for measurements of dermal resistance, the Pain Trace ${ }^{\mathrm{TM}}$ device can pick up small voltage differences between two areas of the skin located on either side of the body without applying any electrical current. It is believed that in mammalian species, regional differences in SPs reflect an asymmetric distribution of the sympathetic and parasympathetic nervous system activity between the left and right side of the body. Under physiological conditions, the sympathetic tone dominates, causing a positive SP voltage between two body sides. In contrast, in subjects experiencing persistent pain of more severe intensity, the autonomic nervous system activity shifts in favor of parasympathetic (particularly vagal) dominance, which in turn causes SP recordings to become more negative [7]. Because pain-induced persistent tachycardia compromises hemodynamic including cardiac pump functions, it is believed that upregulation of the parasympathetic nervous activity in response to pain fulfils a cardioprotective function. Therefore, it has been proposed that SP readings could serve to objectively detect and quantify nociception and pain perception in dogs [8]. 
To the best of the authors' knowledge, no studies have yet been published to demonstrate the usefulness of SP readings as a tool for assessing nociception and pain sensation in dogs. Therefore, the aim of this study was (1) to obtain baseline SP readings at three different sites/areas (neck, axilla, and thorax) in pain-free dogs in an attempt to identify the optimal site(s) for SP recordings and to compare those with recordings obtained in pain-free human subjects (study Part 1); and (2) to assess whether this device allows for reliable detection of pre-operative (i.e., at the time of hospital admission) nociception/pain in dogs experiencing pain associated with cranial cruciate ligament disease, as a model of persistent pain (study Part 2).

\section{MATERIALS AND METHODS}

The study was approved by the Research Ethics Committee for both animals and human volunteers (AREC \& HREC) of the University College of Dublin, Ireland in December 2010. A questionnaire to assess pain-free status was administered to the owners and human volunteers prior to collecting data. The study was performed in conformance with the Declaration of Helsinki's ethical guidelines. Informed consent has been obtained for client-owned animals included in this study.

\section{Study Part 1}

Twelve dogs ( $<5$ years old) and 12 human subjects $(<30$ years old) were recruited, with equal numbers of female and male subjects. The dogs were admitted to the University Veterinary Hospital (UVH) for elective surgery (ovariohysterectomy and castration). They were considered to be healthy based on their history and clinical examination. The human subjects were volunteers recruited at the University College of Dublin through poster announcement.

The inclusion criterion was being pain-free, in order to determine whether the readings were comparable between species. The exclusion criteria were: showing any sign of discomfort or receiving any analgesic medication (non-steroidal anti-inflammatory or other), and for human subjects, smokers and females who were menstruating. These criteria were assessed through a questionnaire that was completed prior to the study.

\section{Study Part 2}

Five dogs (2 castrated males and 3 neutered females, weighing 26-48 kg) requiring elective stifle surgery were included in this pilot study. The owners provided informed consent for the recruitment of their animal into the study. They were considered to have persistent pain based on their history of lameness of long duration and clinical findings consistent with cranial cruciate ligament disease. Any non-steroidal antiinflammatory (NSAIDs) or other analgesic drugs were withheld 24 hours prior to surgery and SP recordings. All SP measurements were obtained pre-operatively. 


\section{Measurement of skin potentials}

Skin potential measurements were taken using the Pain Trace ${ }^{\mathrm{TM}}$ device (Model 103A, Biographs Inc, Bayville, NY, USA) (Fig. 1). The unit allows skin surface voltage recordings in a manner similar to an electrocardiograph. In the dogs, SP was recorded in the neck, axilla, and chest. No detergent or alcohol was used to clean the electrode sites before attachment. In cases where the skin was dirty, the area was cleaned with water and air dried. A disposable $\mathrm{Ag} / \mathrm{AgCl}$ ECG electrode (Blue Sensor ECG Electrodes Water Gel, Ambu, Cambridgeshire, UK) with saline conductive gel pre-applied by the manufacturer and equipped with a self-adhesive collar was applied to the hairless area. In the human subjects, the hands were washed before the experiment in order to remove skin oils and create better electrical contact, and dried using disposable towels. The measurements were made by applying the self-adhesive electrodes to the center of the palmar surface in each hand. The subjects remained in a relaxed/comfortable position.

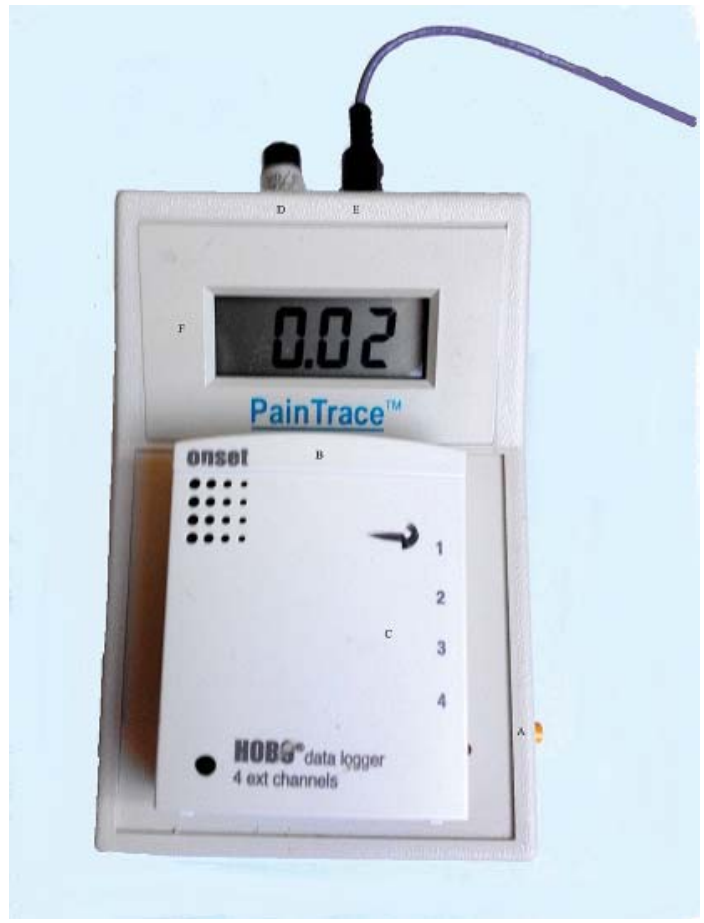

Figure 1. The Pain Trace ${ }^{\mathrm{TM}}$ device: A-on/off button; B-hobo data logger-box; C- four ports for connecting the logger to the device; D-amplifier port; E-cable port; F-display.

Once the electrodes were placed on either side of the body (Fig. 2), wire leads were snap-locked to them and then connected to the Pain Trace ${ }^{\mathrm{TM}}$ device via a $22 \mathrm{k} \Omega$ resistor box that had previously been turned on. 
The recording was started after a 10 -seconds stabilization period. We recorded one sample per second for 90 seconds, for a total of 90 data points per subject. The voltage drop across the resistor generates a current in the microampere range that can be sensed by the Pain Trace ${ }^{\mathrm{TM}}$ device. After appropriate software processing (see below), the signal was transformed into a graphic signal. The device was set to a sensitivity of $1 \mathrm{mV}$ for full deflections, to allow for clear visualization of the signal trace. After SP recording was completed, the electrodes were removed from the subjects' skin and the data were downloaded to the hard drive of a computer and analyzed using the HOBOWARE PRO software (Version 3.1.2, Onset, MA, USA). The amplitude of the deflections depicted on the computer screen represents the difference in SP between the sites of the right and left electrodes. A positive SP with an upward deflection of the trace was considered as indicating lack of pain, while a negative SP with a downward deflection of the trace was considered to indicate moderate to severe pain. The individual animal and human data were averaged over the 90 -second recording period.

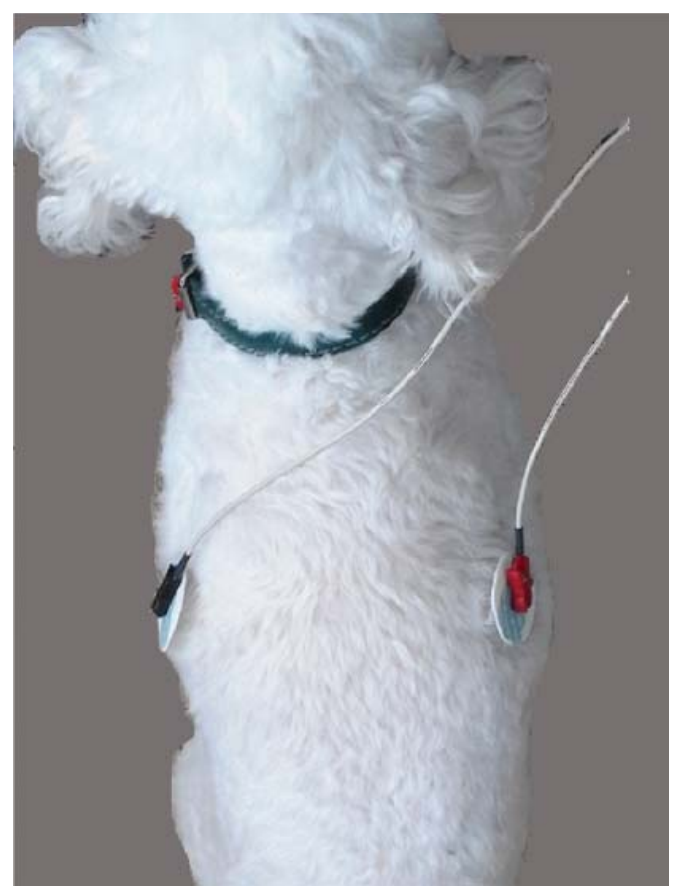

Figure. 2. Example of electrode placement for skin potential reading in a dog (thorax).

\section{Statistical analysis}

\section{Study Part 1}

We conducted this pilot study with the intention to obtain baseline data in canine subjects. The data from male and female dogs, and human subjects were initially analyzed separately, then pooled. 
Initially, the data were analyzed for a potential difference in SPs between pain-free dogs and human subjects. Then the variability in SP readings between the different sites of recordings in dogs (neck, axilla, and chest) was assessed. Finally, the SP measurements obtained from dogs and humans were visually compared by boxplots [9].

Descriptive statistics was obtained through the summary function. We analyzed differences among the median measurements using the Kruskal-Wallis test, which is a non-parametric, rank-based test, the results of which are not affected by the distribution of measurements. P values $<0.05$ were considered as indicating statistically significant differences.

\section{Study Part 2}

Based on the results of study Part 1, the percentages of positive and negative SP readings were calculated in order to assess the accuracy of the pre-operative pain assessments.

Informed consent: Informed consent was obtained from both the owners of the dogs and the human volunteers in study Parts 1 and 2 .

\section{RESULTS}

\section{Study Part 1}

The SP recordings at all sites in dogs and humans were positive, and were characterized by a greater variability in the canine compared to the human study population. Readings from the axilla were the most heterogeneous, with median values lower than those at the other sites. Recordings from either side of the thorax delivered the most homogeneous data among those obtained in dogs, as shown by the low variability of the data and the absence of outliers (Fig. 3 and Table 1). No significant differences were found among the median SP readings in dogs or in humans $(p=0.62)$. The mean SP readings were also very similar across the sites (Table 1).

Table 1. Skin potential (SP) data (in $\mathrm{mV}$ ) in human and canine subjects

\begin{tabular}{llccccccc}
\hline & Site & Min & 1st Qu & Median & Mean & 3rd Qu & Max & SD \\
\hline Human & Palm & 1.2 & 1.22 & 1.23 & 1.23 & 1.24 & 1.26 & 0.02 \\
Dog & Neck & 0.94 & 1.23 & 1.23 & 1.24 & 1.29 & 1.43 & 0.13 \\
& Axilla & 0.73 & 1.06 & 1.18 & 1.25 & 1.3 & 1.97 & 0.37 \\
& Thorax & 1.10 & 1.19 & 1.23 & 1.23 & 1.26 & 1.37 & 0.08 \\
\hline
\end{tabular}

Min: minimum, Max: maximum, $1^{\text {st }}$ Qu: First quartile; 3rd Qu: Third quartile, SD: standard deviation. 


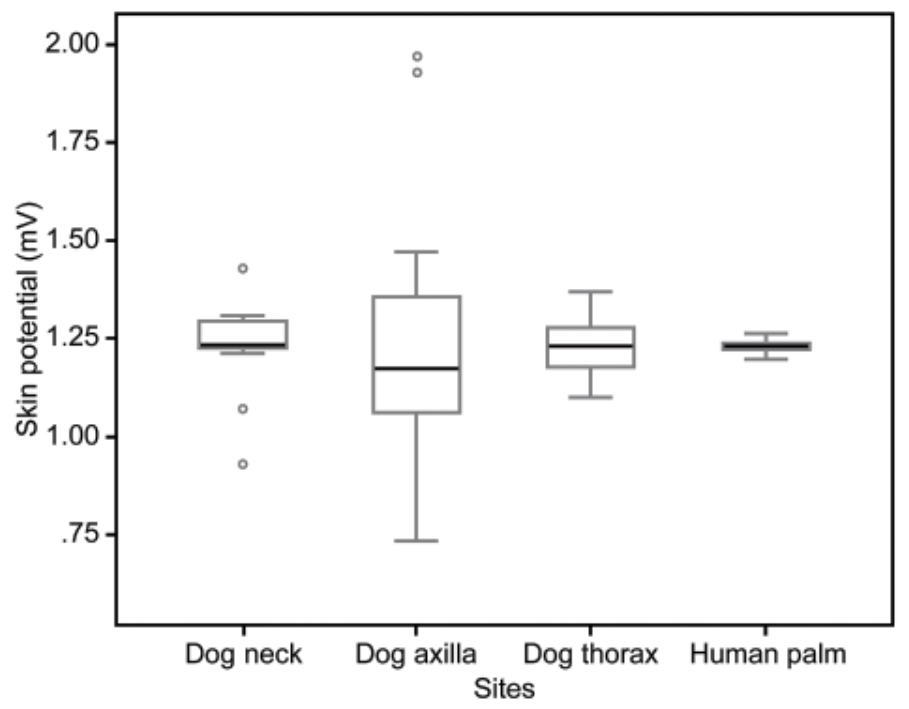

Figure 3. Boxplot of skin potential readings at different sites in dogs and in humans. The bottom of the box represents the first quartile of the distribution, and the top, the third quartile. The bold bar inside the box represents the median. Small circular symbols indicate values differing from boxes by more than 1.5 times the interquartile range.

\section{Study Part 2}

The SP readings in the five presumably painful dogs were evaluated. All dogs undergoing corrective orthopedic stifle surgery were visibly lame (non-weight-bearing) with pain on palpation at the time of admission and analgesia had been withdrawn 24 hours before the recordings and surgery. Based on the results from study Part 1, the thorax was chosen as the site for electrode placement. The negative SP readings were expected to appear in the preoperative period. However, all SP readings were in the positive range (Table 2).

Table 2. Skin potential (SP) data (in $\mathrm{mV}$ ) recorded from canine thorax: study Parts 1 and 2

\begin{tabular}{lccccccc}
\hline & Min & 1st Qu & Median & Mean & 3rd Qu & Max & SD \\
\hline Study 1 & 1.10 & 1.19 & 1.23 & 1.23 & 1.26 & 1.37 & 0.08 \\
Study 2 & 1.23 & 1.60 & 1.64 & 1.55 & 1.64 & 1.67 & 0.18 \\
\hline
\end{tabular}

Min: minimum, Max: maximum, 1st Qu: First quartile, 3rd Qu: Third quartile, SD: standard deviation.

\section{DISCUSSION}

Being unable to express pain is an issue that pertains not only to animals but also to children (infants), the cognitively impaired, patients who have lost speech function, and comatose patients. Even though self-reporting is the gold standard in humans for assessment of the site, nature, and severity of pain, it is not applicable in animals 
or non-verbal humans [10]. As early as 1883, Lord Kelvin stated that the ability to effectively treat pain (both in the animal and human patient) is dependent on how well the pain can be measured. However, pain and nociception are difficult to recognize, measure, and quantify in non-verbal humans and animals [11].

While there are multiple subjective methods of pain assessment, objective means of assessment are currently limited. Furthermore, the available methods often do not assess the experience of persistent or background pain but instead serve to quantify the response to noxious stimulation (often referred to as 'procedural pain'). For example, the pressure applied to a surgical incision site that is necessary to elicit a nocifensive response in the animal, or the latency of a withdrawal or nocifensive response can both be quantified. Other objective methods of pain assessment often involve the use of stronger mechanical or thermal stimuli, which often are not applicable in clinical settings due to the risk of tissue injury upon repeated stimulation.

The physiological effects of enhanced sympathetic nervous system (SNS) activity, such as accelerated heart rate and elevated blood pressure, are not considered to be reliable indicators of pain, although they can be quantifiably measured [12]. Further, these sympathetic effects do usually not persist for long after the initial noxious stimulation, likely due to a subsequent compensatory increase in parasympathetic tone as the body seeks homeostasis [7].

It is well known that persistent exposure to a moderate to severe noxious stimulus evokes an increase in SNS tone [7]. However, it was discovered only in 1981 that long-lasting pain that is strong enough to trigger baroceptor responses also evokes an increase in the parasympathetic nervous system (PSNS) tone, often referred to as vagal tone [13]. Increased PSNS activity triggers a physiological endogenous opioid-mediated pain relief mechanism [14] that is naloxone-reversible. Its antinociceptive action was first observed in rats and can be reversed by dissection of the right vagal nerve trunk [13]. In mammals, the right vagal nerve trunk acts to partially counteract nociception by triggering the release of endogenous opioid peptides such as endorphins within the central nervous system. This has been shown in rats [15] and other mammals [13, 16] including cats [17], monkeys [16], and humans [17-19]. Because vagal nerve fibers also innervate the skin [20], it was suggested that pain-induced increase in vagal tone in the right vagal trunk could be responsible for shifts in the SP difference between the right and left side of the mammalian body, which can be detected by skin electrodes.

Thus, it has been hypothesized that in subjects with persistent moderate to severe pain, the Pain Trace ${ }^{\mathrm{TM}}$ device would reveal a negative voltage reading as the PSNS tone increases. This idea was supported by findings in rats that electrical stimulation of the vagal afferents produced partial pain relief $[16,21]$. It has additionally been suggested that ongoing monitoring of SPs can help to evaluate the efficacy of analgesic agents, where successful pain relief would be reflected as a change from negative to positive voltage readings. Initial data in humans and horses seem to support this idea. In humans, SP readings before and after pain produced a shift in the trace from positive 
to negative voltages that seemed to follow the magnitude of self-reported pain and in some instances, the voltage amplitude of the linear trace also corresponded well with the severity of pain sensation reported by the human subjects. In every case in these studies, SP readings during the painful state were negative, while readings during the pain-free state were positive $[5,6]$.

As no baseline SPs have been reported in dogs, the purpose of study Part 1 was to first establish baseline SP values in pain-free dogs (at neck, axillary, and thorax locations) and to compare these with data from pain-free humans (palmar surface of the hand). All the readings were positive, as expected, because the subjects were all pain-free. There were no significant differences in the median $\mathrm{mV}$ values between dogs (all sites) and humans. The readings in dogs were characterized by a greater variability with several outliers noted when SP was recorded in the neck and axilla areas, while recordings across the chest/thorax were associated with the lowest variability.

We compared three different electrode sites to determine the optimal site for measurement and whether all of them provided signals strong enough for recording. We noted more difficulty in firmly positioning the adhesive electrodes on the dogs at the neck and axillar sites as compared to the human palm, due to much greater mobility of the skin in those areas of the canines. In dogs, the skin over the thorax is under much greater tension than in the other tested areas. Therefore, the electrodeto-skin adhesion is thus more consistent, thereby producing less variability in voltage readings over time. Thus, it seems the chest is the optimal site to place the electrodes in awake dogs. We chose the thorax as the best site for electrode placement in conscious dogs, and used it for the canine patients in study Part 2.

For the clinical cohort study, it was important to assess a homogenous group of female and male subjects since there are recognized gender differences in pain perception, as shown by studies performed in humans and rats [22]. In this population of painfree dogs, the measured values were comparable to those of pain-free humans. Based on previous work in humans and horses, negative SPs can only be evoked when the subject is in a state of moderate to severe pain $[5,6]$. We thus selected dogs with an obviously painful condition (persistent lameness as a result of severe cranial cruciate ligament disease). Any analgesics were discontinued 24 hours prior to testing. In this group of animals, despite clinical signs of significant pain before surgery, the results of the SP voltage readings were all positive (Table 2).

Based on our findings, the presence of moderate to severe pain does not necessarily lead to negative voltages in the SP trace. This might indicate that the Pain Trace ${ }^{\text {TM }}$ device may not reliably allow quantifying pain as moderate to severe, at least in this group of dogs. It is also possible that pain must reach greater intensity before PSNS activity increases, thereby resulting in a negative trace. In the equine and human studies, in which the Pain Trace ${ }^{\mathrm{TM}}$ device allowed tracking of changes in SP following noxious stimulation, pain was evoked by chronic back pain in the human patients and more severe musculoskeletal diseases in horses, and the stimulation was more severe/ 
stronger. We anticipated that the severity of the joint disease/cranial cruciate ligament disease in the dogs enrolled in this study was severe enough and the duration was long enough to have triggered changes in the autonomic (particularly the PSNS) nervous system activity. Of course, one might speculate whether PSNS activity might have decreased over time and thus lost its impact on SP readings. Our findings suggest that nociception needs to be strong enough and persistent to trigger proper changes in autonomic nervous system activity and hence SP, i.e., an acute pain model would not be suitable for this device.

It should be noted that analgesics in the dogs in study Part 2 were withdrawn for what might be considered an insufficient period ( 24 hours). However, it is unlikely that this confounded the results, because all the animals displayed lameness of long duration with pain on palpation on the day of surgery prior to the induction of anesthesia, which indicates at least moderate pain.

In summary, the absolute values and variability of baseline SP recordings with the Pain Trace $^{\mathrm{TM}}$ device in pain-free subjects were similar between dogs and humans. However, in a population of canine patients with cranial cruciate ligament disease, the device was unable to detect a shift to negative SPs in animals before surgery, when analgesics had been withheld.

\section{Author's contributions}

GP drafted the manuscript. GP, BR and DB participated in the design of the study, performed the statistical analysis, conceived of the study, and participated in its design and coordination and helped to draft the manuscript. All authors read and approved the final manuscript.

\section{Declaration of conflicting interests}

The author(s) declared no potential conflicts of interest with respect to the research, authorship, and/or publication of this article.

\section{REFERENCES}

1. Reid J, Nolan AM, Hughes JML, Lascelles D, Pawson P, Scott EM: Development of the short-form Glasgow Composite Measure Pain Scale (CMPS-SF) and derivation of an analgesic intervention score. Anim Welf 2007, 16:97-104.

2. de Erausquin GA, Pitra JC, Rey RB, Faiman CP, Baratti CM: A novel non-invasive method to measure skin potential response: Some pharmacological evidence. Methods Find Exp Clin Pharmacol 1989, 11:765-770.

3. D'Angelo D: (947): Skin potential as a correlate of moderate to severe chronic pain - A case report. J Pain 2006, 7:S86. 
4. D’Angelo D: (895): Computer-compatible, portable method of measuring Skin Potential (SP) as a correlate of chronic pain - a case report. J Pain 2007, 8:S74.

5. Ngeow JY, D'Angelo D, Wang D: Charge Density Pulse (CDP) device as an objective indicator of pain - a preliminary report. 11th World Congress World Congress of International Society for Pain ${ }^{\circledR}$ - IASP, Sydney, Australia, 2005.

6. Ngeow J, Wang D, Burke J: (894): Assessing post-surgical pain and pain relief by measuring skin potential assymmetry in a non-verbal (equine) population. J Pain 2007, 8:S74.

7. Heller PH, Perry F, Naifeh K, Gordon NC, Wachter-Shikura N, Levine J: Cardiovascular autonomic response during preoperative stress and postoperative pain. Pain 1984, 18:3340.

8. Rialland P, Authier S, Guillot M, Del Castillo JR, Veilleux-Lemieux D, Frank D, Gauvin D, Troncy E: Validation of orthopedic postoperative pain assessment methods for dogs: A prospective, blinded, randomized, placebo-controlled study. PLoS One 2012, 7:e49480.

9. R Core Team: R: A language and environment for statistical computing. R Foundation for Statistical Computing, Vienna, Austria. [http://www.R-project.org]

10. Mathew P, Mathew J: Assessment and management of pain in infants. Postgrad Med J 2003, 79:438-443.

11. Anil SS, Anil L, Deen J: Challenges of pain assessment in domestic animals. Aust Vet J 2002, 220:313-319.

12. Hansen B: Acute pain management. Vet Clin North Am Small Anim Pract 2000, 30:899_ 916.

13. Maixner W, Randich A: Role of the right vagal nerve trunk in antinociception. Brain Res 1984, 298:374-377.

14. Ren K, Randich A, Gebhart GF: Vagal afferent modulation of a nociceptive reflex in rats: involvement of spinal opioid and monoamine receptors. Brain Res 1988, 446:285-294.

15. Thurston CL, Randich A: Electrical stimulation of the subdiaphragmatic vagus in rats: inhibition of heat-evoked responses of spinal dorsal horn neurons and central substrates mediating inhibition of the nociceptive tail flick reflex. Pain 1992, 51:349-65.

16. Randich A, Gebhart GF: Vagal afferent modulation of nociception. Brain Res Brain Res Rev 1992, 17:77-99.

17. Bossut D, Whitsel EA, Maixner W: A parametric analysis of the effects of cardiopulmonary vagal electrostimulation on the digastric reflex in cats. Brain Res 1992, 579:253-260.

18. Ness T, Fillingim RB, Randich A, Backensto EM, Faught E: Low intensity vagal nerve stimulation lowers human thermal pain thresholds. Pain 2000, 86:81-85.

19. Zamir N, Maixner W: The relationship between cardiovascular and pain regulatory systems. Ann N Y Acad Sci 1986, 467:371-384.

20. Kaji A, Shigematsu H, Fujita K, Maeda T, Watanabe S: Parasympathetic innervation of cutaneous blood vessels by vasoactive intestinal polypeptide-immunoreactive and acetylcholinesterase-positive nerves: histochemical and experimental study on rat lower lip. - Neuroscience 1988, 25:353-362.

21. Randich A, Aicher SA: Medullary substrates mediating antinociception produced by electrical stimulation of the vagus. Brain Res 1988, 445:68-76.

22. Wiesenfeld-Hallin Z: Sex differences in pain perception. Gend Med 2005, 2:137-145. 


\section{PILOT STUDIJA REGISTROVANJA ELEKTRIČNOG POTENCIJALA KOŽE U CILJU ODREĐIVANJA NOCICEPCIJE KOD PASA I OSOBA U ODSUSTVU BOLA I KOD PASA SA PERZISTIRAJUĆIM BOLOM}

\section{GIORDANO Paola, BENNETTT C Rachel, DRIESSEN Bernd}

Uređajem Pain Trace ${ }^{\mathrm{TM}}$ mogu da se detektuju promene električnog potencijala kože, za koje se smatra da su povezane sa promenama aktivnosti u simpatičkom i parasimpatičkom nervnom sistemu. Pozitivna voltaža znači odsustvo bola, a negativna voltaža predstavlja bol srednjeg i jakog intenziteta. Za razliku od ljudi i konja, do sada nisu objavljeni rezultati koji se odnose na bazični električni potencijal kože kod pasa. U prvom delu studije, beleženi su bazični potencijali kod zdravih pasa, koji su poređeni sa očitavanjima koja su dobijena na ljudima dobrovoljacima. Kod pasa, podaci su dobijeni pomoću elektroda koje su postavljene na tri različite lokacije na telu psa: vrat, aksila i toraks. Kod ljudi, podaci su dobijeni sa dorzalne strane šake. Očitavanja tokom perioda od 90 sekundi, bili su prosečni, a poređenje između grupa je obavljeno upotrebom Kruskal-Wallis testa. Sva očitavanja voltaže su bila pozitivna. Podaci koji su dobijeni od pasa varirali su u većem stepenu. Podaci dobijeni sa toraksa bili su ujednačeniji. Iz tog razloga, ovaj situs je odabran za drugi deo studije. Nisu uočene značajne razlike između pasa i ljudi u podacima u odsustvu bola. Osnovna hipoteza je bila da promena od pozitivne ka negativnoj voltaži potencijala kože, može da bude pokazatelj prisustva bola srednjeg i jakog intenziteta kod pasa. Otuda, obavljeno je preoperativno očitavanje kod pasa sa oboljenjem kranijalnog krucijalnog ligamenta, kod kojih je bio stalno prisutan bol. Ovi podaci su upoređivani sa očitavanjem kod pasa kod kojih nije postojao bol (toraks). Kod pasa koji su podvrgnuti hirurškom tretmanu, sve voltaže pre operacije bile su pozitivne pa nije bilo moguće uspostaviti povezanost između očitavanja vrednosti potencijala kože i osećanja bola. Da bi se potvrdila bilo kakva korelacija, neophodno je da se nastavi sa ispitivanjem povezanosti između potencijala kože i stepena bola kod pasa. 